Studies in African Linguisticss

Volume 27, Number 1, Spring 1998

\title{
PROSODICALLY-CONDITIONED VOWEL SHORTENING IN CHINDALI *
}

\author{
Robert Botne \\ Indiana University
}

\begin{abstract}
In Chindali [Bantu M21, northern Malawi and southern Tanzania], the augment vowel of noun classes $1 \mathrm{a}, 5 \mathrm{a}, 9$ and 10 exhibits allomorphic variation in length. In other noun classes, the vowel of the noun class prefix varies in length before NCinitial stems. The author demonstrates that, in both cases, potentially long vowels become shortened, except that they do so under different conditions: mora-count of the noun stem in the first case, lack of high tone (accent) on the prefix in the second.
\end{abstract}

\section{Introduction}

A prominent characteristic of Bantu languages is their noun class system, in which there may be as many as twenty-one different classes. Each class is associated with a characteristic prefix - usually $\mathrm{cv}$ - or $\mathrm{N}$ - in form-and, in some languages, with an augment, usually a single vowel that precedes the class prefix. Hence, a typical noun will have the canonical form $\mathrm{VJ}_{\mathrm{J}}-\mathrm{CVJ}$-STEM. Such is the case in Chindali, a Bantu language spoken in northern Malawi and southern Tanzania (M.21 in Bastin's [1978] modification of Guthrie's [1967-71] zone classification). The focus of this paper is shortening of potentially long vowels of the augment or class prefix vowel.

Nouns in Chindali that do not have the canonical $\mathrm{VJ}_{\mathrm{J}}-\mathrm{CVJ}$-STEM form-that is, nouns of the form V-STEM, V-N-STEM-exhibit allomorphic variation in the length of the pre-stem vowel. This phenomenon is illustrated in the contrast between

\footnotetext{
* I wish to acknowledge and thank Loveness Schafer, my primary informant, for long hours of patient discussion of her language. I also thank Larry Hyman, David Odden, Stuart Davis, and Dan Dinnsen for comments that have led to a much better understanding and presentation of the data on my part. I remain solely responsible for interpretation of the data and the views expressed.
} 


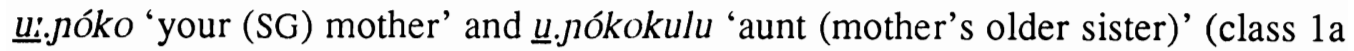
nouns), î.vala 'scar' and í.va'nda 'blood' (class 5 nouns), ím.béva 'mice' and im.bê:mbe 'horns (of cow)' (class 10 nouns). Nouns of the form V-CV-[NCV..]STEM exhibit variation in the length of the class prefix vowel, hence, umu.ndá:la 'old man' and umúl.chindali 'Chindali person' (class 1 nouns). What is interesting about these two cases of variation is that they are prosodically conditioned: vowel length is sensitive to the mora count of the stem in the case of the non-canonical pre-stem vowels, to the presence of a high tone in pre-stem position in the case of the class prefix vowels. The objective of this paper is to describe and analyze these phenomena in the northern Malawi variety of Chindali and to suggest a possible historical scenario for the occurrence of mora-conditioned shortening.

\section{Noun classes in Chindali}

Chindali has eighteen true noun classes, paired into eleven singular-plural genders. ${ }^{1}$ One class-class 15 -is never paired in Chindali, being reserved for verb infinitives/gerunds. These classes are partially distinguished morphologically by the type of class prefix they permit, and partially by the nature of the concordial agreement they determine on modifiers and verbs. Figure 1 below provides a listing of these forms for each of the classes as well as a pairing of the singularplural genders.

Figure 1. Noun class augments and prefixes

\begin{tabular}{|c|c|c|}
\hline \multicolumn{3}{|c|}{ Singular } \\
\hline Cl. \# & Augment & Prefix \\
\hline 1 & $u-$ & $m u-$ \\
\hline $1 \mathrm{a}$ & $u:-/ u-$ & \\
\hline 3 & $u-$ & $m u-$ \\
\hline 5 & $i-$ & li- \\
\hline $5 a$ & & $i=-/ i-$ \\
\hline 7 & $i-$ & $\check{c}_{i}-$ \\
\hline 9 & $i-/ i-$ & $n-$ \\
\hline 9 & i-/i:- & n- \\
\hline 11 & $u-$ & lu- \\
\hline 12 & a- & ka- \\
\hline 14 & $u-$ & $v u-$ \\
\hline 15 & $u-$ & $k u-$ \\
\hline
\end{tabular}

\begin{tabular}{|c|c|c|}
\hline Plural & & \\
\hline Cl. \# & Augment & Prefix \\
\hline 2 & $a-$ & va- \\
\hline $2 a$ & a- & vO:- \\
\hline 4 & $i-$ & $m i-$ \\
\hline 6 & a- & ma- \\
\hline 6 & a- & ma- \\
\hline 8 & $i-$ & $f_{i-}$ \\
\hline 6 & a- & ma- \\
\hline 10 & $i-/ i i^{-}$ & $n-$ \\
\hline 10 & $i-/ i^{\prime}-$ & $n-$ \\
\hline 13 & $u-$ & tu- \\
\hline 6 & a- & ma- \\
\hline
\end{tabular}

1 Data were collected primarily from Loveness Schafer, a native speaker of Ndali, over a period of 28 months, from September 1995 to December 1997. Additional data were collected from written texts collected from $\sim 30$ native speakers in northern Malawi during May-June 1995. 
Several classes require special comment. First, classes 1a and 2a, which historically included nouns referring to special categories of humans (e.g., kinship relations), now include other nouns, such as some body parts and some animals, separating them semantically from classes 1 and 2 , which still include only human nouns. Morphologically, the class 2a prefix vo:- represents a case of double prefixation: class 2 va-plus the class 1 a augment $u$ :-

Second, of 101 nouns collected in classes 5 and 5a, only 19 are inherently found in class 5 ( $19 \%$ of the total). Class $5 \mathrm{li}$ - occurs before both C-initial and Vinitial roots-for example, ili.ko:ndo 'type of yam', ilí.líma 'bean', íly.a:ni 'leaf'unlike the case in many other eastern Bantu languages in which it occurs only before vowel-initial roots. This is quite possibly a consequence of borrowing from neighboring languages. Also unusual for class prefixes, a few words have alternate forms, i.e., both the class 5 and class 5 a prefixes are possible, as, for example, in ili.fumu versus î.:fumu 'sub-chief'. Whether this is due to dialectal or individual variation is not clear. It is not the case that the class 5 a form is derived phonologically from the class 5 form. As evidence of this, forms like ilílíma 'bean' cannot become $\check{i}$ :lima. Furthermore, class 5 ili-functions productively as an augmentative, as in íli.kuku 'huge chicken' (<î:I.guku 'chicken'); it cannot occur as $*_{i}: k u k u$.

Third, the class 9 and 10 prefix $-n$ - varies in form according to the initial segment of the root. Before vowels and /y/, it remains [n]; compare, for example, $1-n-$ o:ve 'fingers' (> i-my-o:ve 'huge fingers'), i-n-(y) û:mba 'houses' (> i-mi-yû:mba 'huge houses'), and î'-n-joka 'snakes' (>i-mi-yoka 'huge snakes'). ${ }^{2}$ Before consonants it becomes homorganic, except before roots beginning with either a spirant (ǐ-swi í-n-gulu [9-fish 9-large] 'large fish') or a nasal (ii-nóma 'drum' vs. i-liநóma 'huge drum'), in which case it is deleted (see (21-22) and (23), respectively, for further examples). These latter forms resemble class 5 a forms, and can be distinguished only by the type of concordial agreement they determine.

\section{The structure of the Chindali noun}

The canonical noun in Chindali is composed of three constituent parts: the stem, the class prefix, and a pre-prefix, which may be either the augment or a locative prefix. The derivational (D-)stem and the class prefix together comprise the inflectional (I-)stem, the augmentless form of a noun occurring after, for example, the copula - $v a$ (or its suppletive form -li), as illustrated in (3) further below. ${ }^{3}$ The canonical shape of a noun, as indicated in (1), is that in which the stem is disyllabic and the pre-D-stem elements are V-CV-.

2 Note that in Ndali stops and affricates-/b, d, j, g/-become continuants- $[v, 1, y$, ur $]$-intervocalically, but do not change following a nasal. Palatal $/ \mathrm{n} / \mathrm{plus} / \mathrm{y} /$ or $/ \mathrm{u} / \mathrm{become}[\mathrm{n}]$ and $[\mathrm{n}]$, respectively.

3 The terms D-stem and I-stem have been adopted here for the structure of the noun following a suggestion by Larry Hyman, based on work on the verb by Laura Downing. 
(1) Canonical form of Chindali nouns

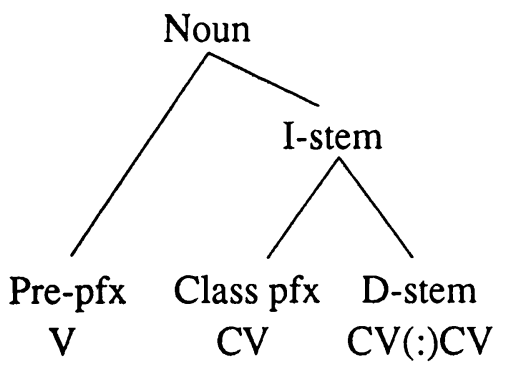

The canonical D-stem in Chindali is disyllabic, though the first syllable of the D-stem may have either one or two moras. Vowels in longer stems may be short or long in any position, illustrated by the examples in (2), except in final position, which is always short.

(2)
a. ú-mu-kolo
i- či- kô:le
b. i-m- balatya
i- fi- byá:liwa
i- $m$ - batâ:ta
u- káine:se
c. a-ká-fweleléma
i- či- fwa:nikíjo
i- či- papáttula
i- ᄁ- galimôto
u-mu-no:mwejô:mwe
i- $m$ - bula:ingê:ti

d. u- kamúfuingulila 'woman'

'girlfriend'

'plantains \& meat'

'crops'

'sweet potato'

'onion'

'period before sunrise'

'example'

'bark used as firewood'

'car'

'unmarried woman'

'blanket'

'circle'

\section{Noun class}

1

7

9

8

9

la

12

7

7

9

1

9

1a

\section{The status of class 1a and 5a prefixes}

Of particular relevance for this study is the status of class $1 \mathrm{a} u:-/ u$ - and class $5 \mathrm{a}$ i:$/ i-$, which are the only classes whose pre-D-stem affixes cannot be readily segmented into an augment and a prefix. They are also the only ones that consist solely of a vowel. Nevertheless, although similar in form, they differ significantly in morpho-syntactic behavior. Class 1a $u$ :-/u- behaves much like an augment of "regular" classes (examples in 3-4): it is deleted following the connective particle $-a$;, as in (5a), and the copula -ba (or suppletive $l i-$ ), as in (5b). And like augments, 
it does not co-occur with locative prefixes. However, class 1a nouns differ from canonical V-CV-prefixed nouns in that the locative is not affixed to the noun in place of the augment, but rather to the connective -a:, as in $(5 \mathrm{c}) .4$

Class 5a i:- differs from class 1a $u$ :- in that its behavior is more like that of the class prefix. Although, like $u:-$, it is deleted following the connective -a:, as in (6a), unlike $u:-$, it occurs optionally following the copula (6b). (It is not clear at this point whether this variation is free or determined by some criterion such as definiteness.) Also, like the canonical CV-prefix (3c), it co-occurs with the locative prefix (6c), hence, the label "A(ugment)-prefix".

(3) Class 1 and locatives of classes 3, 5,6
a. iné:tua yá: mwa:na 'marriage of a child' [< ú-mw-a:na 1 'child'] 9-marriage 9-of 1-child
b. ukuvá múlume
AUG-15-be 1-husband
c. pa-mu-sé:vo
mú-ly-i:so
mú-ma-piji
'to be a husband'
'on the road'
'in the eye'
'in among the
millet stalks'
[< ú-mu-lume 1 'husband']
[< u-mu-sé:vo 3 'road']
[< i-ly-isso 5 'eye']
[<á-ma-pifi 6 'millet stalk']

(4) Class 9
a. pakavalílo ka: sála 'in a time of famine' [< i:-sála 'famine'] 16-12-time 12-of famine
b. yá:ba jgúvo 9-Pf-be 9-cloth
'it was a cloth'
$[<i-\mu-g u ́ v o$ 'cloth']
c. pa-m-bû:ngo
ku:-síla
mû:-futyo
'at the funeral'
'on the path'
'in the pot'
[<i-n-bû:ngo 'funeral']
$[<i:-(n-)$ síla 'path']
$\left[<\hat{\imath}_{\text {i- }}(n-)\right.$ futuo 'path']

(5) Class 1a
a. amá đu tuá: kalulu 6-word 6-of hare
'words of Hare'
[< ú-kalulu 'hare']
b. ukuvá malafyâ:le 'to be a chief' AUG-15-be 1-chief
c. p-a: เuô:ndo $k w$-a: uyô:ndo mw-a: páfwa
'at the mound' [<u-ıyô:ndo 'mound']
'on the mound' [<u-luôindo 'mound'] 'inside (of) the lung' [< u:-páfwa 'lung']

4 As noted earlier in the text, the u:-, unlike the canonical augment, is retained in the plural. Moreover, it also occurs in the form wi: + STEM $(/ \mathrm{u}:+\mathrm{i} /)$, a relative copular-like construction. 
(6) Class 5a
a. umpwâ:to wă: viue 1a-noise 1-of rock
'noise of the rock'
[< i:-bwe 'rock']
b. likuvá (i:) Jiku
'it is a day'
$[<$ i:-fiku 'day']
5-Pr-be 5-day
c. $p$-í--Jiku
$k w-\check{i}$-vue
mw-i:-ưúlu
'on the day'
'on the rock'
'in the maize
[<i:-fiku'day]
granary'
[<i-vure 'rock']
[< i--ıuúlu 'maize granary']

The set of locative prefixes (7) are often grouped in Bantu grammars together with the set of noun class prefixes. Like class prefixes, they determine concordial agreement on modifiers and verbs. However, like the augment, with which they do not co-occur, they precede the class prefix. Of relevance to this paper, they also exhibit allomorphic variation in vowel length, as illustrated by the examples in (7).

(7) Locative prefixes (with class $9 / 10$ nouns)

Cl. \#

16 pa-/pa:- pa-n-û:mba 'at a house' vs. pa:-n-úma 'upper back'

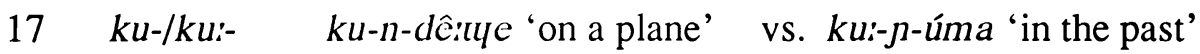

$18 \mathrm{mu-/mu:-}$ mu-ı-gú:mbe 'in the pot' vs. mûs-furyo 'in the pot'

A more extensive general description of the northern Malawi Chindali noun class system can be found in Vail [1974]. However, although Vail does indicate (some) phonemic short/long contrast in D-stem vowels, he does not indicate where predictable vowel length occurs and, hence, does not mention the prosodic variation in pre-D-stem vowel length to be described here.

\section{Variation in the length of classes 1a and 5a pre-stem vowels}

Nouns in classes 1a and 5a-that is, those which deviate from the canonical V-CVpre-D-stem structure-may differ in pre-stem vowel length, the distribution of the long and short variants dependent on the moraic count of the D-stem, long vowel before mono- and bi-moraic stems, short vowel before longer stems. Representative data are given first for class 5a nouns (8) which have the variants [u:-] and [u-].

(8) Class 1a
$\begin{array}{ll}\text { a. ú:- vuvi } & \text { 'spider' } \\ \text { u:- pína } & \text { 'her mother' } \\ \text { u:- páfwa } & \text { 'lung' }\end{array}$
u- vî:sa
$u$ - nô:ingi
ú- tă:ta
$u$ - mă:nga
ú- sč:la
'rooster'
'so-an-so'
'my father'
'pumpkin'
'leopard' 

b. ú:- kavıua 'dog'
ú- kavuji
u- jókokulu
u- káya:mba
u- malafyâile
c. u:- mbépo 'god'
ú- mba:mbo 'father (priest'
u- mbútuulu 'owl'
ú- ndǔ:li
u- ngópole
ú- ngwa:ngu

The set of examples in (8a) contrasts disyllabic D-stems that differ in the length-and, hence, in the mora count-of their medial vowel. The set in ( $8 \mathrm{~b})$ shows bimoraic versus tri- and quadri-moraic stems, while that in (8c) illustrates length differences before $\mathrm{NC}$-initial stems.

The class 5 a prefix behaves phonologically in the same way as the class 1a augment, the only difference being the vowel quality, [i] rather than [u]. Contrasts between pre-D-stem long vowels with bi-moraic stems and pre-D-stem short vowels with multi-moraic stems (i.e., more than 2 moras) are shown in (9).

(9) Class 5a

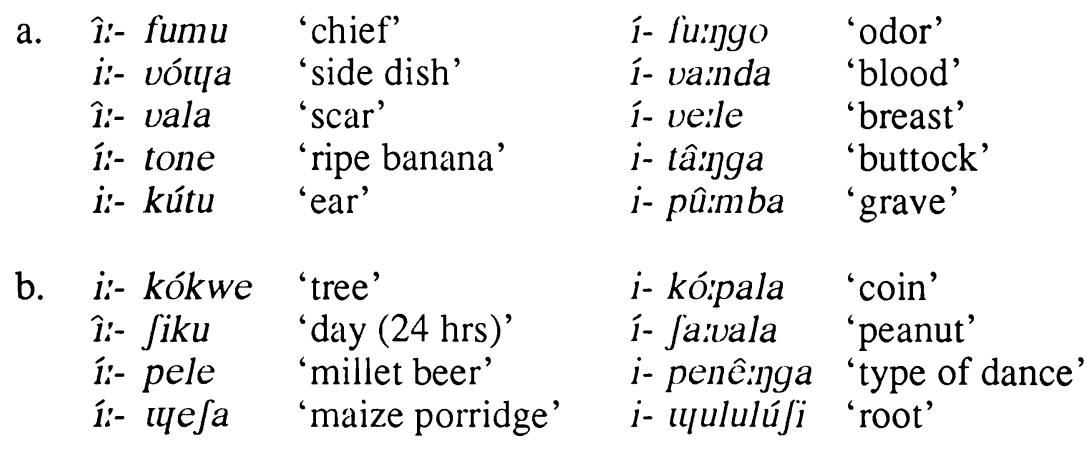

\section{c. î:- noli 'type of wild fruit' i-ndřma 'lemon'}

The examples in (9a) contrast disyllabic D-stems, those in (9b) show bimoraic vs. tri- and quadri-moraic D-stems. The two examples in (9c) show the prefix before $\mathrm{N}$ - and NC-initial stems.

That the long pre-D-stem vowel noted in the left-hand examples of (9) above does not occur in nouns having canonical V-CV-STEM form is attested by the examples in (10), in which the same underlying D-stem is illustrated with both canonical prefix and 5a-prefix pre-D-stem morphology. 


\begin{tabular}{|c|c|c|c|}
\hline (10) a. & 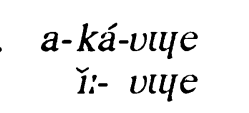 & $\begin{array}{l}\text { 'small rock' } \\
\text { 'rock' }\end{array}$ & $\begin{array}{l}12 \\
5 \mathrm{a}\end{array}$ \\
\hline b. & $\begin{array}{r}i-c ̌ i-k o ́ k w e \\
i-k o ́ k w e\end{array}$ & $\begin{array}{l}\text { 'stick; wood' } \\
\text { 'tree' }\end{array}$ & $\begin{array}{l}7 \\
5 \mathrm{a}\end{array}$ \\
\hline c. & $\begin{array}{r}u ́-v u-\int i k u \\
\hat{I}-\text { - } \int i k u\end{array}$ & $\begin{array}{l}\text { 'night' } \\
\text { 'day' }\end{array}$ & $\begin{array}{l}14 \\
5 \mathrm{a}\end{array}$ \\
\hline d. & $\begin{array}{r}\text { u-tu-vótya } \\
\text { i:- vótua }\end{array}$ & $\begin{array}{l}\text { 'a delicious side dish' } \\
\text { 'a side dish' }\end{array}$ & $\begin{array}{l}13 \\
5 \mathrm{a}\end{array}$ \\
\hline e. & $\begin{array}{r}\hat{1}-\text { li- vala } \\
\hat{1} \text { - vala }\end{array}$ & $\begin{array}{l}\text { 'long, ugly scar' } \\
\text { 'scar' }\end{array}$ & $\begin{array}{l}5 \\
5 \mathrm{a}\end{array}$ \\
\hline
\end{tabular}

\section{Length variation in classes $9 / 10$}

The same variation in pre-D-stem vowel length is found among nouns of classes 9 and 10, which are composed of an augment, a nasal class prefix, and the stem$\mathrm{V}+\mathrm{N}+\mathrm{STEM}$. Classes 9 and 10 are identical in their pre-D-stem morphology; they differ only in the type of concordial agreement they determine. However, since class 10 functions as the plural of both classes 9 and 11, examples from both classes will be included.

The basic underlying form of the class $9 / 10$ prefix is $/ \mathrm{n} /$. Thus, if the noun Dstem is vowel initial, as in the examples in (11), which are all derived from verbs, and in those in (12), which are the plurals of class 11 nouns, the noun class prefix surfaces as [n]. Note that in all of these cases, the D-stem is tri-moraic or longer and that the pre-D-stem vowel is short.

(11) Class 9: in-

$$
\begin{aligned}
& \text { í- } n \text { - e:tua 'marriage' [<u-kw-ê:tla 'marry'] } \\
& i \text { - } n \text { - a:ngálo 'games' [< u-kw-áingala 'play'] } \\
& i-n \text {-inónono 'thought' } \quad[<u-k w-i \text { ' } \quad \text { ónona 'think'] } \\
& \text { i- n-i:pû:to 'pastor, priest' } \quad[<\quad u \text { - } k w \text {-i:pû:ta 'pray'] }
\end{aligned}
$$

(12) Class 10: in-
a. i- n- â:la
i- $n$-o:ve
'grinding stones'
'fingers'
b. u-lw-â:la 'grinding stone'
i- $n$ - î:ho
'customs'
ú-lw-o:ve 'finger'
i- $n$ - i:mbo
'songs'
u-lW-î:ho 'custom'
ú-lw-i:mbo 'song'

With a stem-initial glide-either $[y]$ or $[\longleftarrow]$ - the features of the the nasal prefix coalesce with those of the glide, hence, $/ \mathrm{n}+\mathrm{y} / \rightarrow[\mathrm{n}], / \mathrm{n}+\mathrm{u} / \rightarrow[\mathrm{\eta}]$, as illustrated 
by the examples in (13). Again, tri-moraic stems occur only with a short pre-Dstem vowel.

(13) Classes $9 / 10 /-n-/$ with glide-initial stems
a. $i$ - $n$ - û:mba 'house'
[AUG = umu-yû:mba]
b. I- ந-ě:nda 'mouse'
[AUG = ili-ı̌ě:nda]
$i$ - $\eta$-ô:mbe 'head of cattle'
[AUG = ili-ưô:mbe]

Before a consonant-initial D-stem, the nasal prefix is always homorganic, as shown by the data in (14)-(20). As in the case of classes 1a and 5a described previously, variation occurs in the length of the pre-D-stem vowel-here, the augment $i$-. As in the cases of $1 \mathrm{a}$ and $5 \mathrm{a}$ nouns, the long variant, $i$--, occurs with stems having one or two moras, the short variant, $i-$, with nouns of three or more moras.

(14) Class 9: i:m- versus im-
a. i:-m-béva 'mouse'
í:- $m$ - bolo 'penis'
í:- $m$ - buno 'nose'
b. i- m-be:ya
'salt'
i- $m$ - bó:mbo
'navel'
i- m- bû:ygo
'disease'
i:-m-báfi 'louse'
i-m-balauya
'plantains \& meat'
î- $m$ - bepo 'wind'
i- m- bilipî:ri
'hot pepper'

(15) Class 9: i:n-versus in-
a. i-n-défu 'facial hair'
í: $n$ - dovo 'pail'
í:-n-dumi
'message'
i:-n- dámyo
'problem'
$\hat{i}:-n-\operatorname{dimi}$ 'tongue'
b. i-n- dyê:la 'maize \& beans'
i- $n$ - dô:ki 'plantain'
i- $n$ - du:ne 'green banana'
i- n- dapatapa
'thigh'
i-n-dacyilo 'rule'

(16) Class 9: i:n-versus in-
a. í- $n$ f̆utua 'language'
i:- $n$ - f̌évo
'slander (cl. 10)'
b. $\quad i-\mu-\breve{f} \hat{u}: k i$
i- $n$ - fe:ye
'honey bee'
i:- $n$ foka 'snake'
$\hat{i}:-n$ - fato 'python'
$i-n$ - f́éčeva
'crab'
'type of charm'

(17) Class 9: i: - versus in-
a. $\check{i}:-\eta-g w i$
'firewood'
I:- $-\eta-$ gelo
'temptation'
b. i- g- gwî̀na
'crocodile'
$i$ - $\eta$ - gé:la
'dew'
i:-n-góle
'blood vessel'
i- - - gŏlla
í-p-guku
'chicken'
í-ᄁ-g gamu
'name'
î:- $\eta$ - gata
'headpad'
$i$ - $\eta$ - gulúve
'phlegm'
i- j-galamu
'pig'
i- ᄁ-gwa:pa
'lion'
'armpit' 
Before voiceless spirants and nasals, the nasal prefix is deleted, as shown in (18)-(19) and (20), respectively. As with the previous cases, difference in pre-stem vowel length varies according to the number of moras in the stem.

Class 9: $i:-$ versus $i$ -

(18)
î:- fula
i:- sála
í:- seko
i:- sófu
a. í- filua
(i- sofu
a. í- nama
i:- nóma
'fish'
'grey hair'

$\begin{array}{ll}\text { I:- } s w i & \text { 'fish' } \\ \text { I:- } f w i & \text { 'grey hair' }\end{array}$

(20)
b. Í-sefulira 'metal pot'
i-fo:ngono 'nosebleed'
b. 1- fuingo 'odor'
i- sû:la 'lopper'
i- sâ:mbo 'wire'
i- sékema 'fever'
í- solyolo 'calf (of leg)'

b. i-jnota 'thirst'

1- 1]činda 'mouse'

i- no:ingwa 'court case'

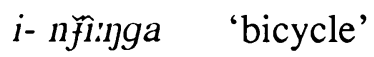

Class 10 (plural of 11): $i$ - versus $i-$

$\begin{array}{ll}\text { i- nu:nda } & \text { 'fishing spears' } \\ \text { i- nu:ngu } & \text { 'wild dogs' } \\ i-\text { nê:je } & \text { 'bumblebees' } \\ i-\text { nầ:ja } & \text { 'tomatos' }\end{array}$

\section{Variation in the vowel length of locative prefixes}

Locative prefixes in Chindali behave morpho-syntactically like augments in that they precede the noun class prefix; they behave like class prefixes in that they determine concordial agreement on modifiers. Again, as in the cases described previously, when the vowel of the locative prefix is the sole pre-stem vowel, as it is when it precedes the nasal class prefix of class 9 or 10 , we observe variation in vowel length depending on the number of moras in the stem. Representative examples of the three locative prefixes with class 9 nouns are provided in (21)(23), showing that the vowel of the locative is long when the stem has no more than two moras, short when there are three (or more) stem moras.

5 Rising and simple high tones on long vowels do not appear to be distinctive in Ndali nouns. That is, there appears to be only a two-way opposition on long vowels: high on the first mora (falling tone) vs high on the second mora (either rising tone or high on both moras). It is not yet clear what conditions the variation; hence, tones are given here as transcribed in my notes. 
Locative + N + STEM

(21) Class 16
a. pa:- $n$ - úma
'upper back'
$p \hat{a}:-(n-) s e^{6}$
'ground, earth'
$\begin{array}{lll}\text { b. pa- } n \text { - } & \text { ûmmba } \\ \text { pá- } 1 \text { - } & \text { ge:lo }\end{array}$
'at the house'
'the early morning' [< i-n-ge:la 'dew']

(22) Class 17
a. ku:- $n$ - úma 'in the past'
kû:- $(n-)$ se 'the outside'

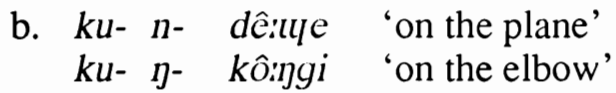

(23) Class 18
a. mu:-m- bófo 'in the medicine'
mú:-n- dete 'in the reeds'
b. mú- $n$ - dă:mba 'in the granary'
mú- $m$ - balalua 'in the potatoes/meat'

Preceding nouns of class 5a, the locative vowel is either lost or becomes a glide (24). The prefix $i$ :- of the noun is long or short, as we have seen previously, depending on the mora count of the stem.

(24) Locative + prefix ii- (cl. 5a)
$\begin{array}{lll}\text { a. } & p-1{ }^{\prime}-\text { Jiku } & \text { 'on the day' } \\ p- & i-p e n e ̂ i n g a & \text { 'at the dance' }\end{array}$
b. $\begin{aligned} & k w-i:-k o ́ k w e \\ & k w-i-p u ̂\end{aligned} \quad$ 'at the tree'
$k$ 'at the grave'
c. mw-i:- kútu 'inside the ear'
$m w-i-$ tê:mbe 'in the kraal'

The locative vowel is not affected when it occurs before a canonical CV-class prefix, as in (25)-(26). The class prefix vowel is long in (25a) and (26a) because the $\mathrm{D}$-stem is NC-initial (the $\mathrm{N}$ being deleted before the voiceless fricative). This issue is discussed at greater length in section 9.

\footnotetext{
6 Recall that in Ndali nasals are deleted when they precede voiceless spirants. Hence, pâ:se derives from $/ \mathrm{pa}+\mathrm{n}+\mathrm{se} /$.
} 
(25)
a. pá-mu:-si
'midday'
cl. 3
b. pá- $(v) u-\int i k u$
'night'
cl. 14

(26)
a. kú-ma:- so
'face'
cl. 6
b. ku-vú- če
'at dawn'
cl. 14
$k u ́-m w-a: j l a$
'sky'
cl. 3
kú-ka- a:ya
'home'
cl. 12

Class 1a nouns differ from all other nouns in that they require the use of the connective -a: when locativized, as illustrated in (27). Augment $u$ :- is deleted from the noun, as are canonical augments. The locative connective form is invariably long, that is, it is unaffected by the stem mora count. What this suggests is that connective -a: is either a separate word or a proclitic on the noun. Although nouns and verbs usually end with a short vowel in Chindali, functional words often have final long vowels (for example, po: 'so then', čočô: 'the one who/that', wê: ' who', nô: 'without'). On the other hand, it may be that the connective structure represents what Hyman and Katamba [1990] analyze as a "word within a word", [CV-a: [NOUN] word] $]_{\text {word. }}$ In either case, the connective is not affected by vowel shortening as are the pre-D-stem affixes.

(27) Locative + -a: + la noun

a. p- a: sapâ:ta 'during the week'

b. kw-á: kavwa 'on the dog'

c. mw-a: má:nga 'inside the pumpkin'

\section{Mora determined length in noun modifiers}

Alternation in pre-D-stem vowel length has thus far been limited to nouns. However, the phenomenon is also found in adjectives, which must agree with the noun. The concordial agreement marker is usually the same as the pre-D-stem morphology of the noun, except in the case of class la nouns, which have the same agreement marker as class $1-u m u-$. In the two sets of data that follow, a bimoraic adjective stem, -nine 'other' and -kulu 'big', is contrasted with a tri-moraic stem, -nâ:ndi 'small, few' and -kesamu 'reddish', similar in segmental composition. Each set comprises three categories: V-STEM, V-N-STEM, and V-CV-STEM. Recall that the nasal prefix of classes $9 / 10$ deletes before nasals and voiceless fricatives.

(28) -nine 'other' versus -nâindi 'few/small'
a. 5a î:fiku í-níne
'another day'
i:kókwe i-nâ:ndi
5 ilyî̀ta ři-níne
'a small tree'
'another name' 
b. 9 imbô:mbo í:-níne 'other work'

10 inô:mbe í:-níne 'other cattle'

c. 1a umâinga u-mú-níne 'another pumpkin'

6 amavúyo a-má-níne 'other places'

8 ififû:kwa i-fî-níne 'other reasons' i:mbáko i-nâindi

'a small cave'

î:nguku i-nâ:ndi

'a few chickens'

uví:sa u-mu-nâ:ndi

'small rooster'

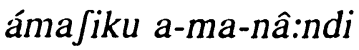

'a few days'

ifijnámâ:na i-fi-nâ:ndi

'a few animals'

(29) -kulu 'big' versus -kesamu 'reddish'

a. 5 i:kókwe î̀-kulu 'a big tree'

b. 9 imbô:mbo î:-tı-gulu 'a lot of work'

10 í:mbufi îi-l-g-gulu 'fat goats'

c. 1a umbê:ıya ú-mu-kulu 'big baboon'

6 amakókwe á-ma-kulu 'big trees'

8 ifikókwe í-fi-kulu 'big pieces of wood' iló:ıgwi í-kesamu

'reddish soil'

indéfu í-n-gesamu

'reddish beard'

inô:mbe í-ᄁ-gesamu

'reddish cattle'

u:kávıla u-mú-kesamu

'reddish dog'

amê:ya a-má-kesamu

'reddish fur'

ifijámầna i-fí-kesamu

'reddish animals'

\section{Length variation in the canonical CV-class prefix}

Nouns having the canonical CV-prefix typically have short vowels in the augment and in the prefix, regardless of the syllabic or moraic structure of the stem, as the representative examples in (30)-(32), illustrating mono-moraic, bi-moraic, and trimoraic D-stems, respectively, demonstrate (apparent exceptions to this are discussed in section 11).

$\begin{array}{ll}\text { u- mú- ko } & \text { 'son-in-law' } \\ \text { i- mí- tu } & \text { 'heads' } \\ \text { a- má- } t i & \text { 'saliva' } \\ \text { u- vú- fwe } & \text { 'death' }\end{array}$

Noun class 
(31)

$\begin{array}{lll}\text { á- va- kolo } & \text { 'women' } & 1 \\ \text { u- mu- lómu } & \text { 'mouth' } & 3 \\ \text { I- či- tuli } & \text { 'mortar' } & 7 \\ \text { u- lu- sáya } & \text { 'cheek' } & 11 \\ \text { a- ka- yúni } & \text { 'bird' } & 12 \\ \text { u- vú- vine } & \text { 'sickness' } & 14\end{array}$

(32)

$\begin{array}{lll}\text { a- vá- li:fa 'men' } & 2 \\ \text { u- mu- tế:jgu 'amount' } & 3 \\ \text { i- či- sá:vi } & \text { 'mound' } & 7 \\ \text { i- m- belele 'sheep' } & 10 \\ \text { a- ka- valílo 'time' } & 12\end{array}$

Although typically short, the vowel of the CV-class prefix is occasionally long. The long CV:- variant only occurs before NC-initial D-stems, as illustrated by the examples in (33)-(36), though not all NC-initial D-stems appear with a long CV:- variant. However, unlike the vowel length alternation noted previously with class $1 \mathrm{a}$ and $5 \mathrm{a}$ nouns, the salient conditioning factor appears not to be the mora count of the D-stem, but rather the positioning of a high tone. Hence, the difference between the nouns on the left-hand side and those on the right-hand side in (33)(36) appears to be the location of the first high tone. Nouns having the first high tone in pre-D-stem position manifest a long prefix vowel, those having the first high tone on the D-stem a short prefix vowel.

(33) Classes $1 / 2$ and $1 \mathrm{a}$
a. u-mûi-ndu 'person' a-vâ:- ndu 'people'
b. u-mú:-chindali 'Chindali person' a-vá:- chindali 'Chindali people'
u-mu-ndá:la old man'
a-va- ndá:la 'old men'
c.
u-mu-ngelê:sa a-va- ngelêssa
'English person' 'English people'
d.

$\begin{array}{ll}\text { u-mu-mbwê:si } & \text { 'close friend' } \\ \text { a-va- mbwê:si } & \text { 'close friends' }\end{array}$

(34) Classes 3/4
a. ú-muí-si
'day'
'days'
b. $i-m \hat{\imath}:-n d u$
'mess' 
c. ú-mu:-sútyu 'today'

(35) Classes 5/6
a. i-li:- $s O$ á-ma:-so

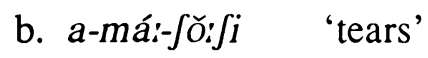
c.

(36) Classes $7 / 8$
a. $i-c ̌ i ́:-n d u$ i-fi:- ndu
'thing' 'things

b. i-čí- chindali
'Chindali language'

c. i-čli- ngaJa 'kitchen area'
d. i-čli- ngwǐ:kwi 'butterfly' i-fi:- ngwřkwi 'butterflies'

$u-m u-n \check{f} i: n g a$ i-mi- nॅ̆linga 'huge bicycle' 'huge bicycles'

$$
\begin{array}{ll}
\text { a-ma-ndìma } & \text { 'lemons', } \\
\text { a-ma-ngalâtsi } & \text { 'mirrors' }
\end{array}
$$

i-či- ndundú:nga 'large basket'

i-fi- ndundú:nga 'large baskets'

i-či- ngelê:sa 'English language'

i-č- i:ngwelê::ji 'on and on'

i-fy-i:ngwelê: $j i$ 'on and on'

e. i-čí- ngǔındya 'leaf (bean plant)'

i-fi:- ngǔ:ndya 'leaves (bean plant)'

The class 3 nouns úmu:si 'day' (34a) and úmu:sútyu 'today' (34b), the class 5 noun illi:so 'eye' (35a), and the class 6 noun amá: $\int{ }_{0}: \int i$ 'tears [of the eye]' (35b) all appear, at first glance, to be exceptional in that there is no overt NC-initial D-stem. However, evidence that the D-stems are/were underlyingly NC-initial comes from comparative data. The word for 'today' is most likely a contraction of úmŭ:si 'day' and úuu 'this'. Guthrie [1967-71]) reconstructs variant forms for 'day' and 'eye' in Common Bantu, one of which has a nasal cluster: *-cí and *-ncí 'day'; *-yícò and *-yịncò 'eye'. In Kinyarwanda (J.61) and Kirundi (J.62), for example, we find umû:nsi 'day'. And in neighboring Inamwanga (M.22) we find il.inso/am.inso 'eye/s' in which the nasal is still extant. Assuming Chindali had the nasal variant of the stem, then we can readily provide an historical reason for the vowel lengthening in these two cases; the NC sequence produced a long prefix vowel (37) but the nasal was subsequently deleted preceding the voiceless spirant.
a. $a+m a+11 n c o ̀ ~>a ́ a t m a:+n s o>a ́-m a:-s o$

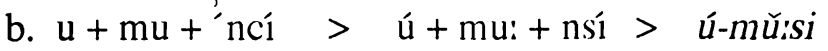


Such lengthening did not occur in other nouns of classes $5 / 6$ or $3 / 4$ for which nasal variants did not occur historically. For example, although 'voice' (38), 'tooth' (39), and 'lower back' (40) resemble the cases of 'eye' and 'day' above, the forms of the nouns and their reconstructions suggest that there was never an underlying $\mathrm{NC}$ cluster.
a. ilí- $\int u$ / amá- $\int u$
b. -jụù $5 / 6$
'voice/s'
'voice'

Common Bantu

(39)
a. íly-i:no / ám-ino
'tooth/teeth'

b. -yínò $5 / 6$

'tooth'

Common Bantu

(40)
a. úmu-sana / ími-sana
b. -cánà $3 / 4$
'lower back/s'
'back'
Common Bantu

Different reconstructions for Common Bantu 'tear' have also been posited: *-ncódị 5/6 'tear from eye' by Guthrie (1967-71), *-icódị by Meeussen (1969). Guthrie's reconstruction appears to be based on the occurrence of an [n]-initial stem in some zone M languages. In neighboring Inamwanga (M.22), for example, we find both initial D-stem segments, il.insozi/am.insozi 'tear/s'. Neither steminitial segment appears in modern Chindali, though they appear to have left a residue of length. In sum, all these examples appear to have (had) NC-initial Dstems, with the nasal disappearing before the voiceless spirant.

Although the focus here is on length variation in the class prefixes, which appears to be dependent on the presence or absence of a high tone in pre-stem position, there is also some variation in length before NC-sequences in D-stems themselves, as for example in iči-ndundû:?gga 'large basket' (36b), in which the [u] is short before [nd] but long before [ng]. This stem internal variation seems to be a consequence of (partial) reduplication. Compare, for example, other reduplicated words which have a short vowel followed by a long vowel before the same NCsequence: umu-činjačîn ja 'killer', i-lambíla:mbi 'bark (for cloth)', and umútengate:nga 'porter'. Non-reduplicative cases such as ama-vuindìndo 'responsibility', show that long vowels before NC-sequences may occur in consecutive syllables. On the other hand, there are some cases of internal length differences which suggest that tone might play a role in vowel length here as well, for example, u-kambô:ni 'marriage representative' versus ú-kaambaku 'bull', in which the first vowel of the stem preceding [mb] is short when the first high tone is on the penultimate vowel, but long when it is on the prefix. For the purposes of this paper, only pre-stem variation will be considered further. 


\section{Discussion and analysis: lengthening or shortening?}

The preceding data and description have shown that pre-D-stem vowels of both nouns and adjectives may appear either long or short. For canonical CV-prefixes, vowel length appears to be contingent on the placement of the first high tone; for non-canonical forms having a single pre-D-stem vowel, i.e., nouns of classes 1a, 5a, 9, and 10, it appears to be dependent on the mora count of the stem. The issue to be considered in this section is whether these constitute cases of vowel lengthening or shortening.

First, vowels in canonical CV-prefixes should be considered underlyingly short. They occur long only in a very restricted, marked environment: before Dstem-initial NC sequences with a concomitatnt pre-stem high tone. Locative prefixes, too, are to be considered short underlyingly. Evidence for this is found in examples such as ku-vú-čc 'at dawn', in which one might expect to find a long vowel, based on the bi-moraic I-stem, but, in fact, finds a short vowel. Since the locative prefixes behave exactly like the class $9 / 10$ augment $i$-, we can surmise that it, too, is also underlyingly short, especially as there is no evidence supporting a long underlying form. Hence, we can conclude that Chindali lengthens pre-stem vowels, as hypothesized in (41), when they immediately precede a stem-initialeither D-stem or I-stem-NC sequence. ${ }^{7}$ This lengthening, then, produces long pre-stem vowels in the following cases: augment $i$ - of classes 9/10; clitics pa-, $k u-$, mu- of locative classes $16,17,18$, respectively; and prefixes having the canonical $\mathrm{CV}$ - form. The alternative-lengthening only in the presence of a high tone-does not fit the data, as the vowel of locative prefixes lengthens before NC-initial Istems of classes $9 / 10$ even if there is not a high tone, as in mu:-mbáko 'in the cave'.

(41) Vowel lengthening before stem-initial NC sequences 8

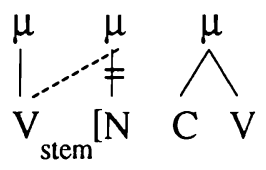

7 Stem internal vowels preceding NC sequences may be either long or short. At this time, it is not clear whether these are best considered in terms of an underlying length contrast or in terms of differentially derived length based on moraic and non-moraic nasals (cf. Hyman and Ngunga [1997] for a similar case in Yao). For example, some words like ngímba [question word] have vowels which precede a nasal cluster do not lengthen. For the purposes of this paper, I only consider pre-stem lengthening.

8 Note that the statements of rules in (36)-(38) are not intended to be rigorous formulations following a particular theoretical view, but rather are intended to provide a general picture of the changes that occur. 
The second issue concerns differences in shortening before NC-initial stems. Two kinds of NC-initial stems have been noted: NC-initial D-stems having canonical CV-prefixes and $\mathrm{N}+\mathrm{C}$-initial I-stems of classes 9 and 10 . Since the two do not behave in an identical manner, two different processes must be accounted for. In the case of canonical CV-prefixes before D-stems, we saw that shortening was precluded by the presence of a high tone in pre-D-stem position, that is, shortening only occurs if there is no high tone preceding the D-stem. We can represent this generalization as in (42).

(42) Vowel shortening in canonical CV-prefixes

$$
\left.\mathrm{V}: \rightarrow \mathrm{V} / \frac{}{[-\mathrm{Hi}]}\right]+\mathrm{stem}[
$$

The second shortening process does not depend on tone and involves the Istem. If we assume classes $1 \mathrm{a}$ and 5a have an underlying long vowel, that is, class 1a $u$ :- and class 5a i:-, rather than an underlying short vowel, we are able to posit a single generalization for the non-canonical forms: long vowels preceding the Istem shorten in just those cases where the noun stem is poly-moraic. That is, if the final moraic unit is considered to be extra-metrical, then shortening can be considered to occur preceding an I-stem that has a bi-moraic "foot". Although it might be tempting to view the class $1 \mathrm{a}$ and $5 \mathrm{a}$ affixes as sequences of two vowels- $\mathrm{u}+\mathrm{u}-$ and $\mathrm{i}+\mathrm{i}-$ - there is no evidence suggesting that they ever behave phonologically or morphologically as two separate elements. In fact, the data and discussion implicitly suggest that in pre-D-stem position Chindali nouns are canonically and underlyingly bimoraic, as in Figure 1.

Figure 1. Canonical and underlying pre-D-stem metrical form

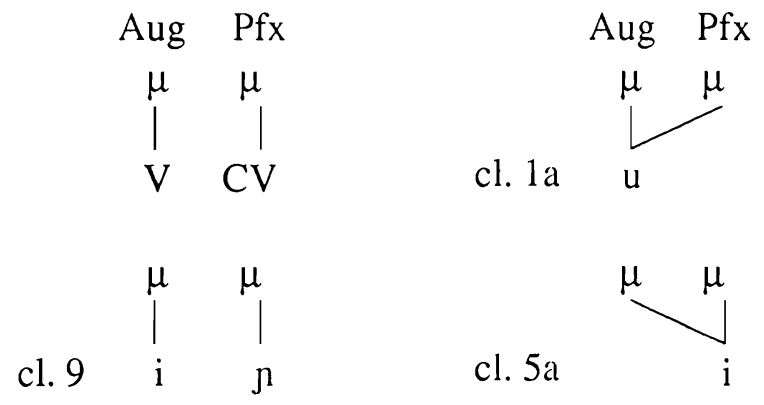

Assuming, then, potential long vowels - either derived from lengthening before $\mathrm{NC}$ or underlying in classes $1 \mathrm{a}$ and $5 \mathrm{a}-\mathrm{vowel}$ shortening is conditioned by the mora count of the stem. This generalization can be represented heuristically as a general rule (43), which must follow the vowel lengthening rule posited in (41) but precede the similar shortening rule in (42). 
(43) Vowel shortening before stems having a bimoraic foot

Foot

$$
\mathrm{v}: \rightarrow \mathrm{v} / \ldots+\operatorname{stem}[\ldots \mu \mu<\mu>]
$$

Two additional rules-vowel deletion and glide formation-account for all variation in pre-stem vowels. As noted in section 2, locatives do not co-occur with the augment, including the class 1a augment $u$ :-. They do, however, co-occur with class 5 a prefix $i$-. In such cases the vowel of locative pa- is deleted (44a), whereas the vowel of $k u$ - and $m u$-forms a glide (44b).

(44) a. /a/ deletion

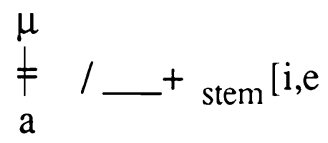

b. Glide formation (2 possible formulations)

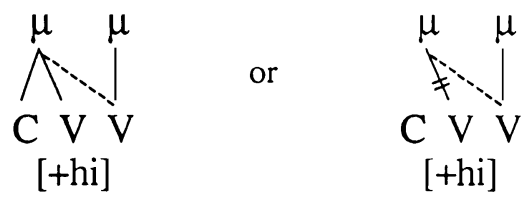

A few examples of each type of pre-stem morphology illustrating the application of these rules are provided in (45). Other phonological changes, such as homorganic nasal shift, are simply assumed, as they have no effect on the vowel issues in question.

(45) Sample derivations

\begin{tabular}{|c|c|c|c|c|c|}
\hline $\begin{array}{l}\text { 'i+či+lundílo/ } \\
\text { "crowd' }\end{array}$ & i+či+lu:ndílo & - & & & [ičilu:ndílo] \\
\hline $\begin{array}{l}\text { /i+čcíchindali/ } \\
\text { 'Chindali } \\
\text { language' }\end{array}$ & 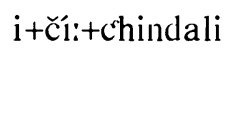 & - & - & & [ičíchindali] \\
\hline $\begin{array}{l}\text { /i+n+dúmbúla/ } \\
\text { 'soul' }\end{array}$ & i:+n+dû:mbúla & - & i+n+dû:mbúla & & [indû:mbúla] \\
\hline $\begin{array}{l}\text { /i:+ndìma/ } \\
\text { 'lemon' }\end{array}$ & i:+ndìma & - & & i+ndì:ma & [indìma] \\
\hline $\begin{array}{l}\text { 'mu+i:+urulu/, } \\
\text { 'in the granary }\end{array}$ & - & mw+i:+щúllu & & - & [mwi:ưúlu] \\
\hline
\end{tabular}

Lengthening Gliding Shorten1 Shorten2 


\section{Some apparent exceptions in vowel length}

Although pre-stem NC sequences and mora count of the stem are, in general, relevant in determining pre-stem vowel length, there are, nevertheless, several exceptions that should be noted. These exceptions are of two types: 1) canonical class prefix vowels which are long even though no NC cluster is apparent, and 2) pre-stem vowels which are long even though the stem has more than two moras.

The first exception has a canonical CV-noun prefix that has a long vowel but which has no apparent NC-conditioned vowel lengthening (46). This case is similar to those mentioned in section 9 for íliso 'eye' and úmü:si 'day'. However, unlike those cases, there is no evidence, historical or comparative, of an NC-initial stem.
a. amá:fuku
[cl. 6a] 'sweat'
b. *-duku 5
'sweat'
[Tervuren reconstruction]

Since the (historical) nasal never appears in words such as ilitso 'eye' and úmǔssi 'day', one might, in contrast with an underlying nasal, propose a segmentless "timing slot" in its place, in which case the stems could be represented as /-:so/ and /-isi/, respectively. ${ }^{9}$ Such a solution would not only avoid underlying segments that do not surface, but also provide an explanation for the case of amá:fuku 'sweat' for which there is no evidence historically of an initial nasal. If an historical form r.fuku existed for Chindali, the shift from class 5 to class 6 suggests that speakers interpreted the vowel segment as the class prefix, but its length as the consequence of a stem-initial segmentless timing slot.

A second exceptional case is that of the noun for "whistling" in (47). Here a canonical CV-prefix does not have a high tone, occurs before a poly-moraic stem, and one which has no apparent $\mathrm{NC}$-initial sequnce, an environment in which a short vowel should occur. The case appears even more exceptional because Chindali has a very similar noun, akalyốno 'the sound $p f k$ ', also derived from a verb, ukufyô:na 'to make the sound $p f k$ ', which does not have a long pre-D-stem vowel. At this time I have no explanation for why this should occur.
(47) a. aka:fyû:nu
b. utu:fyûinu
[cl. 12]
[cl. 13]
'whistling' [< u-ku-fyû:n-a 'whistle with the lips'] 'whistlings'

A final exception is the borrowed word ú:mbula:si 'ambulance'. As a class 1a word, similar to úmba:mbo 'father [priest]', we would expect a short initial [u] since the stem has more than three moras, i.e., it has a bimoraic foot. It would appear, however, that the word has followed the pattern of canonical prefixes before NC-initial stems. That is, it has not shortened the prefix vowel because the prefix has a high tone, which, as has been shown, precludes shortening in canoncial

${ }^{9}$ This suggestion comes from David Odden (personal communication). 
prefixes. This suggests that tone-becoming more stress-like in nature-may be in the process of replacing moraic stem count as the primary factor conditioning vowel shortening.

(48) ú:mbula:si [cl. 1a] 'ambulance'

\section{Reanalysis and restructuring}

As the preceding description has made clear, synchronically Chindali has a prosodically conditioned rule of vowel shortening that affects pre-stem long vowels-noun class prefixes and clitics. What has not been indicated as yet is how it came to be this way. However, comparison with several related eastern Bantu languages provides the basis for a tentative hypothesis. Consider first length in class 5 nouns, a class which exhibits "aberrant" behavior in many languages.

In addition to Chindali, two other central eastern Bantu languages-Chiyao (P.21) and Kimatuumbi (P.13) (see (50) and (51), respectively) - exhibit pre-stem allo-morphic length variation in class 5 dependent on the mora count of the stem. In the northeast of the Bantu zone, Kikuria (E.43), which exhibits contrasting vowel length in stems (52), also exhibits a length contrast in the class 5 vowel, but there it is dependent on syllable, not mora count, as evidenced by the examples in (53). Variants of the augment+prefix are tabulated for each of these languages, contrasted with non-lengthening counterparts in Ruhaya (J.22), a northeast Bantu language (54). [Note that vowel length here is indicated by doubled vowels.]

(50) Kimatuumbi [Odden 1996]
a. liii-wé 'stone'
b. liii-kúti 'coconut leaf'
c. li-bígii 'beer area'
d. lị-kálaala 'bird net'

(51) Chiyao [Ngunga 1997]
a. dii-wú
'ashes'
c. di-véélé
'breast'
b. dii-tivi
'valley'
d. di-sejele
'bead apron'

(52) Kikuria [Cammenga 1994]
a. iri-síisi
'safari ant'
b. iri-sísi
'forest, bush'

(53) Class 5 vowel lengthening in Kikuria
a. irii-wá
'flower'
b. irii-hóá
'thorn'
c. iri-Yóri
'fenced enclosure'
(Note: [óá] is a monomoraic diphthong
d. iri-ßééra
'guava'
[D. Odden, p.c.]) 
(54) Class 5 reflexes

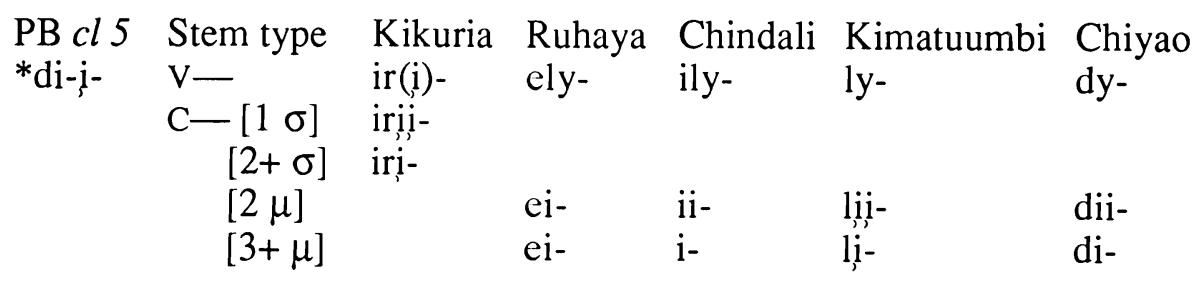

Chindali is similar to Kimatuumbi and Chiyao in that it exhibits allomorphic variation dependent on stem mora count, to Kikuria in that they both contrast length in the class 5 vowel and have a vowel augment, to Ruhaya in that they have added an augment vowel, but lost the reflex of $*$ d except before $V$-initial stems.

Historically, reconstructed Proto-Bantu (PB) class 5 *di-j- exhibits two aberrations with respect to canonical noun class patterns. First, the CV-V-structure deviates from the canonical V-CV- structure of most other noun classes. Second, the CVV- syllable structure creates a heavy syllable word-initially. The data in (54), in addition to the fact that most eastern Bantu languages reduced the vowel length in all instances of the class 5 prefix, suggest that the various languages "resolved" these aberrations in slightly different ways. ${ }^{10}$ Given the conditioning environments observed in those languages that exhibit allomorphic variants-mono-syllabic vs. poly-syllabic in Kikuria, bi-moraic vs tri-moraic in Chindali, Chiyao, and Kimatuumbi-the most likely point of origin would seem to be the dichotomy found in the two prominent stem types among eastern Bantu nouns: -CVCV vs. -CVVCV. Two factors would appear to be salient to the change: position of prominence and minimal word size. If the change began with -CVVCV stems in all these languages, the observed changes readily fall out. In dii-CVVCV words, the atypical word-initial heavy syllable, the adjacency of two potentially heavy syllables, and a shift to preferred penultimate prominence "resolved" the issue by shortening the initial prefix vowel, hence di-CVVCV. However, in the languages investigated here, the same preference for penultimate prominence and a constraint on minimal word size apparently conspired to maintain the length in monosyllbic stems-dii-CV. That is, shortening of the prefix vowel was interpreted as prosodically conditioned. In languages such as Kimatuumbi and Chiyao, which reduced *dii- to $l, i-/ d i-$, respec-

10 I wish to thank Larry Hyman and Thilo Schadeberg for their lively and extensive comments and discussion about historical issues related to class 5 noun prefixes. The ideas expressed here owe much to their discussion, but may not reflect their views.

Information on Haya is from Byarushengo [1977]. The transcription of Kuria vowels in (5253) has been changed from that given by Cammenga (1994) in order to make a uniform comparison of vowels in all the languages. Note, too, that Cammenga states that iri-occurs before $\mathrm{C}$-initial stems, ere- before $\mathrm{V}$-initial stems, a phenomenon typical of E.40 languages (Larry Hyman, p.c.). However, Sillery (1936) gives eli-for class 5, suggesting that Kuria now has vowel harmony at play in the prefixes. I use the form ir, $i$ - to reflect this difference. 
tively, before -CVVCV stems, 11 the syllabically "light" variant, $l i-/ d i$, was construed in terms of stem mora size, the minimal stem being bi-moraic. Thus, bimoraic - CVCV stems remained unaffected by the shortening. In languages like Kikuria, on the other hand, the resulting ri-vs ri,i-dichotomy was construed in terms of stem syllabe count, the minimal stem being mono-syllabic. Hence, the short allomorph spread to all poly-syllabic stems, while the long allomorph was retained before mono-syllabic stems.

Two other changes require consideration: formation of a glide before V-initial stems and addition of an augment vowel in langauges like Kikuria, Ruhaya, and Chindali. The issue with glide formation concerns dii-VCV forms in languages like Kimatuumbi and Chiyao in which bi-moraic -CVCV stems retained the long vowel in the class 5 prefix. If penultimate prominence was prosodically preferred, then a shift of moraic weight from the ante-penultimate vowel to the penultimate voweldii-VCV to dy-VVCV—with concomitant gliding of the high vowel seems likely.

An augment vowel was added in Kikuria, Ruhaya, and Chindali, apparently via analogy with other noun classes. Prefix forms in Ruhaya suggest that the point of origin of the analogy was with $V$-initial stems. That is, the formation of a glide before V-initial stems, producing ly-, appears to have been the catalyst for augment epenthesis. However, Ruhaya, unlike Kikuria, then lost intervocalic prefix [1], leaving $e i-$.

Let us now summarize the case of Chindali. Like Chiyao and Kimatuumbi, Chindali reduced $*$ dii- to $l i$ - before $-\mathrm{CVVCV}$ stems, which led to interpretation of the $l i$ - vs. $l i i$ - variation as prosodically conditioned allomorphy-involving shortening of the long vowel-dependent on the mora count of the stem, the minimal stem being bi-moraic. Before $\mathrm{V}$-initial stems the prefix vowel lost its moraic weight in favor of the adjacent penultimate vowel. As in Ruhaya, an epenthetic augment was inserted before the $l y$ - on $\mathrm{V}$-initial stems and, subsequently, [1] was deleted.

Shortening of the long underlying $\mathrm{ii}$ - variant in Chindali class 5a most likely was extended to class $9 / 10$ prefixes which also had an "aberrant" prefix form-a nasal-and an augment vowel [i]. This form, syllabified as i.NCV.CV with disyllabic stems, looks very much like class 5a nouns; in fact, it was noted in $\$ 5$ that the nasal prefix is deleted in Chindali before voiceless spirants and other nasals, making them look exactly like class 5a nouns. From here, the shortening rule was extended to the class 1 a augment $u$-.

\section{Conclusion}

Chindali has been shown to have two synchronic, prosodically conditioned rules of vowel shortening affecting long pre-stem vowels in nouns and adjectives. One rule

11 Shortening of the heavy dii- or lii- prefix may also reflect a propensity to avoid successive heavy syllables. However, I have found no evidence to substantiate this view at this time. 
shortens canonical class prefixes just in case they do not have a pre-D-stem high tone. The second rule is dependent on the mora-count of the D-stem: minimal bimoraic vs. poly-moraic stems of three or more moras condition the shortening. This latter prosodically conditioned shortening appears to represent a restructuring of the reconstructed Proto-Bantu class 5 noun prefixes *di-i-. What would have been a long vowel before all stems has been preserved only before mono- and bimoraic stems, having been reduced to a short vowel elsewhere. The point of origin of this change was likely to have been -CVVCV stems, which served as a catalyst for reducing the weight of the prefix syllable in deference to potential penultimate prominence and a $\mathrm{CV}$-prefix that matched more closely the canonical noun class prefix in form.

\section{REFERENCES}

Bastin, Yvonne. 1978. "Les langues bantoues." In Barreteau, Daniel (ed.), Inventaire des Études Linguistiques. Paris: Conseil International de la langue Française. Pp. 123-85.

Byarushengo, Ernest Rugwa. 1977. "Preliminaries." In Byarushengo, E., A. Duranti, and L. Hyman (eds.), Haya Grammatical Structure. SCOPIL 6. Los Angeles: Dept. of Linguistics, University of Southern California. Pp. 1-16.

Cammenga, Jillert. 1994. "Kuria Phonolgy and Morphology." Ph.D. dissertation, Vrije Universiteit te Amsterdam.

Guthrie, Malcolm. 1967-71. Comparative Bantu, 4 volumes. Farmborough, England: Gregg International Publishers, Ltd.

Hyman, Larry M. and Francis Katamba. 1990. "Final vowel shortening in Luganda." Studies in African Linguistics 21,1: 1-60.

Hyman, Larry M. and Armindo S. A. Ngunga. 1997. "Two kinds of moraic nasal in Ciyao." Studies in African Linguistics 26,2: 131-164.

Meeussen, A. E. 1969. Bantu lexical reconstructions. Tervuren: Musée Royal de l'Afrique Centrale.

Ngunga, Armindo S. 1997. "Class 5 allomorphy in Ciyao." Studies in African Linguistics 26,2: 165-192. 
Odden, David. 1996. The Phonology and Morphology of Kimatuumbi. Oxford: Clarendon Press.

Sillery, A. 1936. "Notes for a grammar of the Kuria language." Bantu Studies 10: 9-30.

Vail, Leroy. 1974. "The noun classes of Chindali." Journal of African Languages 2,3: 21-47.

Department of Linguistics

Memorial Hall 322

Indiana University

Bloomington, IN 47405

botner@indiana.edu
[Received June, 1997; revision received May 1998; accepted May, 1998] 
